\title{
Comparative efficacy of topical tetracaine solution versus lidocaine gel in cataract surgery
}

\author{
Roberto Bellucci' \\ Francesco Bellucci² \\ 'Ophthalmic Unit, Department \\ of Neurosciences, Hospital and \\ University of Verona, Verona, Italy; \\ ${ }^{2}$ Faculty of Psychology, University \\ of Parma, Parma, Italy
}

\author{
This article was published in the following Dove Press journal: \\ Open Access Surgery \\ I February 2012 \\ Number of times this article has been viewed
}

Correspondence: Roberto Bellucci Ophthalmic Unit, Department of Neurosciences, Hospital and University of Verona, Piazzale Stefani I, 37 I 26 Verona, Italy

Tel +39347 657500 I

Fax +390458122289

Email robbell@tin.it
Background: Cataract surgery is mainly performed under topical anesthesia achieved either by tetracaine solution $(0.5 \%-1.0 \%)$ or gel $(0.5 \%)$, or by $2 \%$ lidocaine gel. This paper reviews the current knowledge about these two drugs, with special emphasis on a published prospective comparison between them.

Methods: The main pharmacological aspects of topical anesthetic agents are summarized, explaining the difference between the ester (tetracaine) and the amide (lidocaine) compounds. Tetracaine is available as single-use eye drops, or as a multidose gel containing benzalkonium chloride, a preservative not contained in the multidose lidocaine gel. A literature search was performed, using "tetracaine", "tetracaine gel", "lidocaine", "lidocaine gel”, "lidocaine jelly", and "cataract surgery" as keywords, and compiling cross-references. A total of 25 studies were identified and included in this review. Of them, seven were uncontrolled studies describing different experiences with the drugs of interest, and 18 were controlled studies. Six studies directly compared tetracaine eye drops or gel with lidocaine gel before cataract surgery.

Results: Both tetracaine solution and gel and lidocaine gel proved to be effective in providing analgesia before cataract surgery. Both drugs were comparable with needle injection anesthesia when intracameral lidocaine was added to topical treatment. Direct comparisons indicate better activity for tetracaine when used at the $1 \%$ concentration in single-dose units, or in the gel form at a $0.5 \%$ concentration. Patients showed a slight preference for the agent that caused the least discomfort when administered (lidocaine), while the surgical complication rate and the surgeon satisfaction were the same with either drug.

Conclusion: Tetracaine solution and lidocaine gel were equally effective in providing topical anesthesia for cataract surgery in the published studies. Tetracaine was found to be better than lidocaine only if augmented by either increasing the concentration to $1 \%$ (solution) or by increasing the penetration by adding benzalkonium chloride (gel).

Keywords: tetracaine, tetracaine gel, lidocaine, lidocaine gel, cataract surgery

\section{Introduction}

Cataract surgery consists of the replacement of the natural lens of the eye that has become cloudy with a new and transparent intraocular lens. It is the most frequent surgical procedure performed in the world, with a yearly rate approaching $1 \%$ of the entire population in Western countries. ${ }^{1}$ The huge number of procedures performed requires a specific approach to management, and several improvements have been implemented in the past for this type of surgery. The eye incision decreased from $12 \mathrm{~mm}$ to $2.2 \mathrm{~mm}$ with the development of phacoemulsification and foldable intraocular lenses that are injected into the eye through special delivery systems. The procedure 
is bloodless, because conjunctival incisions are no longer performed. Immobilization of the eye is not required, in that the surgeon can directly stabilize the eye by two instruments inserted $90^{\circ}$ apart through two small incisions. The procedure lasts only 10-15 minutes in uncomplicated cases, with a very high success rate. Intraoperative and postoperative complications are very low, with the most feared one being endophthalmitis, which is well below $0.1 \% .{ }^{2}$ Cataract surgery is performed on an outpatient basis, and bilateral simultaneous surgery has been advocated. ${ }^{3}$

As a result, the retrobulbar or peribulbar needle anesthesia that had been used for more than a century was almost entirely abandoned about 15 years ago in favor of a new type of anesthesia, which only requires application of anesthetic drops. ${ }^{4,5}$ Topical anesthesia has been adopted in cataract surgery because there is no blood in cut or touched tissues that could remove the anesthetic drug, eyeball akinesia is no longer required, the procedure is usually short, additional anesthesia by either drop or needle can be applied at any time, and there is no risk of globe perforation by needles. ${ }^{6,7}$

Anesthetics topically applied to the eye act directly on the corneal epithelium and stroma, and the portion of drug penetrating into the anterior chamber suppresses pain arising from the iris and ciliary body. The duration of effect of topically applied anesthetics depends on the properties of the drug used. Usually it lasts up to 15-20 minutes for the commonly used agents, but eye drop instillation or intracameral irrigation can be repeated at intervals during surgery if needed. The intraocular muscles are affected by topical/intracameral anesthesia, producing mydriasis, but there is no way to block extraocular muscles or to obtain akinesia of the eyeball.

The advantages of topical anesthesia over periocular injections include not only a higher safety level, but also better consistency of analgesia during surgery and lower intraocular pressure. Furthermore, the limited amount of drug used limits the general side effects commonly observed with local anesthesia. ${ }^{8,9}$ The return of sensitivity soon after surgery allows prompt discovery of any unexpected ocular pain suggesting complications.

Almost all the existing anesthetic drugs have been employed topically for cataract surgery. ${ }^{10}$ From the very beginning, we understood that only unpreserved drops were effective in practice, because drug preservatives caused temporary swelling of the corneal epithelium that prevented a clear view of the details of surgery. ${ }^{11,12}$ Therefore, some preparations became more popular, with different opinions and preferences across surgeons. Because not all of them are available across countries, the availability and selection is somewhat limited. In this review, we focus on tetracaine solution and on lidocaine gel, because these two drugs represent the prototype of their category, and are currently the most widely used in the world.

\section{Pharmacology}

The sensitive terminations of the fifth cranial nerve are concentrated in the cornea and ciliary body in the anterior part of the eye. These fibers are generally nonmyelinated type A-delta and type C. They are able to transmit the sensations of pain, temperature, and touch, and are blocked by lower concentrations of drugs in comparison with motor fibers. The number of nerves involved determines the level of pain, and for this reason corneal abrasions are far more painful than corneal penetrations. To suppress pain, sensitive nerves have to be blocked by anesthetic agents along the nerve itself, or at its sensory terminations. Sensory termination block is the most important feature of topical anesthesia. It involves the inhibition of sodium channels at nerve endings or receptors by the anesthetic agents, thus blocking the production (and not the transmission) of nervous impulses.

Surface anesthetics used in ophthalmology are tertiary amines composed of an aromatic hydrophobic ring, usually benzene, and an amidic hydrophilic group, with an ester (proparacaine, tetracaine, benoxinate) or an amidic (lidocaine, etidocaine, mepivacaine, ropivacaine) intermediate chain. ${ }^{13}$ The properties of the drug (potency, onset and duration of action, selectivity) are determined by the chemical configuration of the two ends of the molecule. The anesthetic agents useful in clinical practice are unstable in their amine form and are insoluble in water. Therefore, they are prepared as salts that are stable in solution at relatively acidic $\mathrm{pH}$. The low $\mathrm{pH}$ of commercially available solutions is the main cause of the burning sensation perceived on first eye drop application. After topical application in the conjunctival sac, the compounds have to be in the nondissociated form to cross the tear film and cornea, and to return to the dissociated form at nerve endings or axons to exert their anesthetic activity. The chemistry of body fluids and the activity of tissue enzymes favor these passages. The ester compounds are rapidly hydrolyzed by plasma esterases and to a lower extent by tissue esterases. The amide compounds are degraded more slowly in the liver, and therefore are endowed with a longer duration of action (Table 1). ${ }^{13}$

General side effects and the potential risks of needle injections are avoided by topical anesthesia, but local side effects can still occur. Inhibition of cellular sodium channels can cause some swelling of the corneal epithelium, especially in older patients, with the possibility of superficial 
Table I Surface anesthetic agents that have been used in cataract surgery

\begin{tabular}{|c|c|c|c|c|c|c|}
\hline \multirow[t]{2}{*}{ Agent } & \multirow{2}{*}{$\begin{array}{l}\text { Concentration } \\
\text { (eye drops) }\end{array}$} & \multicolumn{2}{|c|}{ Action (minutes) } & \multirow{2}{*}{$\begin{array}{l}\mathrm{pH} \\
\left(25^{\circ} \mathrm{C}\right)\end{array}$} & \multirow[t]{2}{*}{ pKa } & \multirow{2}{*}{$\begin{array}{l}\text { \% base } \\
\text { (pH 7.4) }\end{array}$} \\
\hline & & Onset & Duration & & & \\
\hline \multicolumn{7}{|c|}{ Ester compounds } \\
\hline Tetracaine & $0.5 \%-1.0 \%$ & 0.5 & $10-15$ & $4.5-6.5$ & 8.5 & $\approx 15$ \\
\hline Tetracaine gel & $0.5 \%$ & $0.5-1$ & $10-20$ & $4.5-6.5$ & 8.5 & $\approx 15$ \\
\hline Proparacaine & $0.5 \%$ & 0.25 & $5-10$ & $5.0-6.0$ & 3.7 & $\approx 75$ \\
\hline Benoxinate & $0.4 \%$ & 0.25 & $5-10$ & $5.0-6.0$ & 2.2 & $\approx 80$ \\
\hline \multicolumn{7}{|c|}{ Amide compounds } \\
\hline Lidocaine & $4.0 \%$ & $2-5$ & $15-20$ & $6.0-6.5$ & 7.9 & $\approx 25$ \\
\hline Lidocaine gel & $2.0 \%$ & $3-5$ & $20-25$ & $6.0-7.0$ & 7.9 & $\approx 25$ \\
\hline Bupivacaine & $0.5 \%-2.0 \%$ & $5-10$ & $20-30$ & $4.5-6.0$ & 8.1 & $\approx 15$ \\
\hline Ropivacaine & $1.0 \%$ & $2-5$ & $15-20$ & $5.0-6.5$ & 8.1 & $\approx 15$ \\
\hline Mepivacaine & $2.0 \%$ & $1-3$ & $10-15$ & $5.5-6.0$ & 7.6 & $\approx 40$ \\
\hline
\end{tabular}

punctate keratitis. ${ }^{11}$ When preservatives are added to the solution, epithelial toxicity is even more pronounced. ${ }^{12}$ Anesthetic interruption of the blinking reflex increases this local toxicity and it is recommended that patients keep their eyes closed after bilateral instillation. These epithelial side effects can reduce corneal transparency during surgery, and warrant reduction of eye drop instillation and adjunctive intracameral anesthetic irrigation. Some of this toxicity can last a few days after instillation, slightly affecting vision.

\section{Tetracaine solution}

Tetracaine was the first anesthetic used topically for cataract surgery, ${ }^{4}$ and is still one of the most widely used. It is available in some countries at concentrations between $0.5 \%$ and $2 \%$. After eye drop application, it rapidly penetrates the cornea, and especially if the $\mathrm{pH}$ has been adjusted to approach the tear film $\mathrm{pH}$ (7.6-7.8). It begins to take action within one minute and lasts for 10-15 minutes. Tetracaine is considered more toxic to the corneal epithelium than other agents, and therefore excessive application should be avoided.

The first clinical reports of tetracaine in cataract surgery appeared in 1993. ${ }^{14-16}$ Although preliminary in many aspects, those early works pointed out the most important features of topical anesthesia, ie, efficacy of the analgesia obtained, a possible decrease of corneal transparency during surgery, a steady rate of surgical complications as compared with peribulbar injections, positive acceptance from the patient point of view, early recovery of vision, and a lack of the obvious risks of needle injection. Since then, countless papers on topical anesthesia have appeared, outlining many different aspects of the procedure. Large field studies demonstrated topical anesthesia to be safe and effective from a populationbased perspective, and demonstrated it to be suitable for use by inexperienced surgeons. ${ }^{17,18}$
Despite this wide demonstration of validity, many variations of the treatment schedule have been proposed to address local needs and the opinions of patients and surgeons. In some instances, topical anesthesia was augmented by subconjunctival or periocular injections, ${ }^{19}$ mainly reflecting some difficulty in changing surgeon mentality and in establishing new relationships with the patient in the operating room. ${ }^{20,21}$

Clinical studies of topical tetracaine anesthesia in cataract surgery include investigations performed to demonstrate the efficacy and safety of the procedure, as shown in Table 2. Interestingly, the conclusions of early smaller investigations ${ }^{22,23}$ were confirmed later on by larger studies ${ }^{24,25}$ concluding that topical anesthesia with tetracaine can be considered safe and effective in cataract surgery. However, adjunctive intracameral injection of lidocaine $1 \%$ significantly influenced one of the studies, and was probably determining the lack of pain when complications prolonged surgery.

Controlled trials comparing topical tetracaine with other types of anesthesia were also carried out (Table 3 ). Those studies demonstrated that tetracaine eye drops alone were less effective than tetracaine reinforced by intracameral lidocaine or by systemic acetaminophen. ${ }^{26-28}$ Tetracaine eye drops alone were also inferior to peribulbar or retrobulbar needle injections. ${ }^{29,30}$ However, the anesthetic efficacy of tetracaine eye drops plus intracameral lidocaine was the same as that of peribulbar injections. ${ }^{31}$ Interestingly, these studies confirmed the importance of $\mathrm{pH}$ of the solution in preventing pain from instillation. ${ }^{32}$

\section{Lidocaine gel}

Amide-bound lidocaine is also one of the most utilized surface anesthetics in ophthalmic surgery, and is the most widely used for intracameral irrigation. ${ }^{33}$ It is available in concentrations of $1 \%-4 \%$, the unpreserved preparation being preferred because 
Table 2 Uncontrolled studies of tetracaine eye drop anesthesia in cataract surgery

\begin{tabular}{|c|c|c|c|c|c|}
\hline Author & Patients (n) & Concentration & Additional treatment & Primary outcome & Secondary outcome \\
\hline Fichman $^{22}$ & 100 & $0.5 \%$ & None & $\begin{array}{l}\text { Blood pressure, heart and } \\
\text { respiration rate unchanged }\end{array}$ & $\begin{array}{l}\text { No need for intravenous } \\
\text { sedation }\end{array}$ \\
\hline Hoh et $\mathrm{al}^{23}$ & 20 & $1.0 \%$ & None & $\begin{array}{l}\text { Quick visual recovery } \\
\text { after the first } 2 \text { hours }\end{array}$ & \\
\hline Monestam et $\mathrm{al}^{24}$ & 736 & $1.0 \%$ & None & $\begin{array}{l}\text { Eye pain } 1.8 \% \\
\text { Poor cooperation } 1.1 \%\end{array}$ & Posterior capsule rupture $5.2 \%$ \\
\hline Irle et $\mathrm{a}^{25}$ & 1010 & $0.5 \%$ & I\% lidocaine intracameral & $\begin{array}{l}\text { Intraoperative pain } \\
(0-10): 1.62\end{array}$ & $\begin{array}{l}\text { Complications }(0.5 \%) \text { did not } \\
\text { increase pain }\end{array}$ \\
\hline
\end{tabular}

of its better local tolerability. The instillation is rather painful because the $\mathrm{pH}$ of the solution is usually lower than 6 . Intraocular penetration depends on the $\mathrm{pH}$ of the solution, and can be increased by repeating instillations. ${ }^{34,35}$ The advantages of lidocaine include a longer duration of action that might be useful in avoiding having to repeat instillations during surgery. However, postsurgical dry eye sensation ${ }^{36}$ might be higher due to the very prolonged anesthetic effect.

The gel formulation of lidocaine is widely used in anesthesiology, otolaryngology, and urology at the $2 \%$ concentration, and has been used in ophthalmology for cataract surgery for several years. ${ }^{10}$ Gel formulations of drugs are considered better for prolonging contact with the eye structures because they are not immediately washed out at the beginning of surgery. In addition, their drying effect on the ocular surface during surgery might be lower than that of aqueous solutions. ${ }^{37}$

Several uncontrolled trials performed during the last 15 years established the value of lidocaine as topical anesthesia for cataract surgery (Table 4). ${ }^{38-41}$ All these studies pointed to a lack of need for additional anesthesia, with the exception of Waheeb who needed to use sedation in $2 \%$ of patients. ${ }^{41}$ In this study, phaco tip insertion was perceived as painful by patients, and this suggests limiting any pressure increase in the anterior chamber during phacoemulsification with topical anesthesia.

Table 3 Randomized studies of tetracaine topical anesthesia in cataract surgery

\begin{tabular}{|c|c|c|c|c|c|c|}
\hline \multirow[t]{2}{*}{ Author } & \multirow{2}{*}{$\begin{array}{l}\text { Patients } \\
\text { (n) }\end{array}$} & \multirow[t]{2}{*}{ Study } & \multirow{2}{*}{$\begin{array}{l}\text { Control } \\
\text { Study versus } \\
\text { control }\end{array}$} & \multirow{2}{*}{$\begin{array}{l}\text { Primary outcome } \\
\text { Study versus control }\end{array}$} & \multirow[t]{2}{*}{ Secondary outcome } & \multirow[t]{2}{*}{$P$ value } \\
\hline & & & & & & \\
\hline Carino et $\mathrm{al}^{26}$ & 60 & $0.5 \%$ tetracaine & $\begin{array}{l}0.5 \% \text { tetracaine } \\
\text { plus intracameral } \\
\text { I\% lidocaine }\end{array}$ & $\begin{array}{l}\text { Pain score }(0-3) \text { higher at } \\
\text { surgery }\end{array}$ & $\begin{array}{l}\text { Surgeon satisfaction } \\
(\mathrm{I}-5) \text { : lower } \\
\text { No patient preference }\end{array}$ & $\begin{array}{l}P<0.019 \text { for pain } \\
\text { score } P<0.001 \text { for } \\
\text { surgeon satisfaction }\end{array}$ \\
\hline Ho et $\mathrm{al}^{27}$ & 124 & $0.5 \%$ tetracaine & $\begin{array}{l}0.5 \% \text { tetracaine } \\
\text { plus intracameral } \\
\text { I\% lidocaine }\end{array}$ & $\begin{array}{l}\text { Intravenous midazolam } \\
\text { equally required in both } \\
\text { groups } \\
\text { Less intravenous fentanyl } \\
\text { required in the intracameral } \\
\text { group }\end{array}$ & $\begin{array}{l}\text { No systemic } \\
\text { complications }\end{array}$ & $P$ not significant \\
\hline Kaluzny et $\mathrm{al}^{28}$ & 160 & $0.5 \%$ tetracaine & $\begin{array}{l}0.5 \% \text { tetracaine } \\
\text { plus I g oral } \\
\text { acetaminophen }\end{array}$ & $\begin{array}{l}\text { Pain score }(0-10) \text { higher at } \\
\text { surgery and postoperatively }\end{array}$ & $\begin{array}{l}\text { No difference in patient } \\
\text { behavior } \\
\text { No significant adverse } \\
\text { events }\end{array}$ & $\begin{array}{l}P<0.0 \text { I for pain } \\
\text { at surgery and } \\
\text { postoperatively }\end{array}$ \\
\hline Johnston et $\mathrm{al}^{29}$ & 81 & $1.0 \%$ tetracaine & $\begin{array}{l}\text { Peribulbar } \\
\text { anesthesia }\end{array}$ & $\begin{array}{l}\text { Pain score }(0-10) \text { lower at } \\
\text { anesthesia higher at surgery } \\
\text { same postoperatively }\end{array}$ & Same patient satisfaction & $\begin{array}{l}P=0.03 \text { for pain at } \\
\text { anesthesia }\end{array}$ \\
\hline Rüschen et $\mathrm{al}^{30}$ & 28 & $1.0 \%$ tetracaine & $\begin{array}{l}\text { Peribulbar } \\
\text { anesthesia }\end{array}$ & $\begin{array}{l}\text { Satisfaction score }(0-3) \\
\text { lower than peribulbar }\end{array}$ & One peribulbar injection & $\begin{array}{l}P<0.0 \text { I for patient } \\
\text { satisfaction }\end{array}$ \\
\hline Fazel et $\mathrm{al}^{31}$ & 564 & $\begin{array}{l}0.5 \% \text { tetracaine } \\
\text { plus intracameral } \\
\text { I\% lidocaine }\end{array}$ & $\begin{array}{l}\text { Retrobulbar } \\
\text { anesthesia }\end{array}$ & $\begin{array}{l}\text { Pain score }(0-6) \text { : same in } \\
\text { the two groups }\end{array}$ & $\begin{array}{l}\text { Same surgical } \\
\text { complications in the two } \\
\text { groups } \\
\text { Complications from } \\
\text { needle injections }\end{array}$ & $P$ not significant \\
\hline $\begin{array}{l}\text { Hamilton and } \\
\text { Claoue }^{32}\end{array}$ & 40 & $1.0 \%$ tetracaine & $\begin{array}{l}0.5 \% \text { Proxy- } \\
\text { methacaine }\end{array}$ & $\begin{array}{l}\text { Pain score }(0-10) \text { higher at } \\
\text { instillation same at surgery } \\
\text { same postoperatively }\end{array}$ & $\begin{array}{l}\text { No additional anesthesia } \\
\text { No intravenous sedation }\end{array}$ & $\begin{array}{l}P<0.0 \text { l for pain at } \\
\text { instillation }\end{array}$ \\
\hline
\end{tabular}


Table 4 Uncontrolled studies of lidocaine anesthesia for cataract surgery

\begin{tabular}{|c|c|c|c|c|c|c|}
\hline Author & Year & Patients (n) & Concentration & Additional treatment & Primary outcome & Secondary outcome \\
\hline Assia et $\mathrm{al}^{38}$ & 1999 & 52 & $2 \%$ & None & $\begin{array}{l}\text { Mean pain score }(0-10) \text { : } \\
0.72 \pm 1.47\end{array}$ & $\begin{array}{l}\text { No additional anesthesia } \\
\text { required }\end{array}$ \\
\hline Kwok et a ${ }^{39}$ & 2006 & 41 & $2 \%$ & None & $\begin{array}{l}\text { Aqueous humor } \\
\text { concentration }\end{array}$ & $\begin{array}{l}\text { Pain score }(0-6) \text { : } \\
\text { Median: I }\end{array}$ \\
\hline $\begin{array}{l}\text { Von Jagow } \\
\text { et } \mathrm{al}^{40}\end{array}$ & 2007 & 45 & $2 \%$ & Intracameral I\% lidocaine & $\begin{array}{l}\text { Visual acuity at } 4 \text { hours: } \\
0.68 \pm 0.18\end{array}$ & $\begin{array}{l}\text { Visual acuity at I day: } \\
0.9 \text { or better in }>60 \%\end{array}$ \\
\hline Waheeb ${ }^{41}$ & 2010 & 300 & $2 \%$ & Benoxinate $0.4 \%$ drops & $\begin{array}{l}\text { No pain } 85 \% \\
\text { Moderate pain } 13 \% \\
\text { Sedation required } 2 \%\end{array}$ & $\begin{array}{l}\text { Discomfort from } \\
\text { high pressure in } \\
\text { anterior chamber }\end{array}$ \\
\hline
\end{tabular}

Studies of lidocaine gel (or jelly) were carried out in the same time frame (Table 5). In a controlled trial, Koch found that lidocaine gel was equivalent to proparacaine drops, and was better only when applied a second time immediately before surgery. ${ }^{42}$ Bardocci et a $l^{43}$ found higher aqueous humor drug levels after use of the gel than after drop application, but those levels were not related to pain sensation in their study, a conclusion that contradicted a previous study of ours..$^{35}$ Another two studies contributed to establishing the place of lidocaine gel in anesthesia for cataract surgery, ie, Sekundo et $\mathrm{a}^{44}$ found it inferior to sub-Tenon injection and Soliman et $\mathrm{a}^{45}$ found it superior to bupivacaine or benoxinate drops. None of these studies identified any complications arising from lidocaine gel application, but the importance of the low $\mathrm{pH}$ in causing burning sensation was confirmed. ${ }^{45}$ For this reason, sometimes another agent gentler on the eye surface is used for reasons of patient comfort. ${ }^{42}$

\section{Comparative studies}

A comparison of the efficacy and safety of tetracaine eye drops and lidocaine gel as anesthetic agents for cataract surgery could help surgeons in the selection of the agent most suitable for specific techniques in a particular group of patients. A total of six comparative studies published between 1999 and 2010 were found in the literature, and are listed in Table 6. As early as 1999, Barequet et al found the efficacy of $0.5 \%$ tetracaine and $2 \%$ lidocaine gel to be similar before and after surgery, but there was a greater need for additional anesthetic drops during surgery with tetracaine. ${ }^{46}$ In a larger study published in the same year, Harman was not able to detect any difference between the anesthetic efficacy of tetracaine eye drops and lidocaine gel, even after measurement of systemic blood pressure, that could be a sign of anxiety and of unreported pain. ${ }^{47}$ The same conclusion was reached by Amiel and Koch in 2007, who considered 100 patients operated on while using the two drugs, both in gel form..$^{48}$ In their study, intracameral anesthesia was required in only one patient who had received lidocaine gel, a case too anecdotal to contradict the findings of Bardocci et $\mathrm{a}^{43}$ regarding better penetration of the drug after gel application.

Most of these studies utilized a visual chart for scoring pain and other sensations. Visual charts only require the patient to set a point between minimum and maximum,

Table 5 Randomized studies of lidocaine gel anesthesia in cataract surgery

\begin{tabular}{|c|c|c|c|c|c|c|}
\hline \multirow[t]{2}{*}{ Author } & \multirow[t]{2}{*}{$\mathbf{n}$} & \multirow[t]{2}{*}{ Study } & \multirow[t]{2}{*}{ Control } & \multirow{2}{*}{$\frac{\text { Primary outcome }}{\text { Study versus control }}$} & \multirow{2}{*}{$\frac{\text { Secondary outcome }}{\text { Study versus control }}$} & \multirow[t]{2}{*}{$P$ value } \\
\hline & & & & & & \\
\hline $\mathrm{Koch}^{42}$ & 180 & $\begin{array}{l}2 \% \text { lidocaine gel } \\
\text { once or twice plus } \\
\text { I\% proparacaine drops }\end{array}$ & $\begin{array}{l}\text { I\% proparacaine } \\
\text { with or without } \\
\text { I\% lidocaine } \\
\text { intracameral }\end{array}$ & $\begin{array}{l}\text { Lidocaine gel better } \\
\text { than drops only } \\
\text { if applied twice }\end{array}$ & $\begin{array}{l}\text { Intracameral I\% lidocaine } \\
\text { the best adjunct agent }\end{array}$ & $\begin{array}{l}P<0.0 \text { I between } \\
\text { gel twice applied } \\
\text { and drops }\end{array}$ \\
\hline $\begin{array}{l}\text { Bardocci } \\
\text { et } \mathrm{al}^{43}\end{array}$ & 107 & $2 \%$ lidocaine gel & $\begin{array}{l}4 \% \text { lidocaine } \\
\text { drops }\end{array}$ & $\begin{array}{l}\text { Pain }(0-10) \text { higher } \\
\text { with drops } \\
\text { Aqueous humor levels } \\
\text { higher with gel }\end{array}$ & $\begin{array}{l}\text { No correlation between } \\
\text { aqueous humor levels } \\
\text { and pain score }\end{array}$ & $\begin{array}{l}P<0.00 \text { I for pain } \\
P<0.00 \text { I } \\
\text { for aqueous } \\
\text { humor levels }\end{array}$ \\
\hline $\begin{array}{l}\text { Sekundo } \\
\text { et } \mathrm{al}^{44}\end{array}$ & 100 & $\begin{array}{l}2 \% \text { lidocaine gel } \\
1 \% \text { lidocaine intracameral }\end{array}$ & $\begin{array}{l}\text { sub-Tenon } \\
2 \% \text { lidocaine }\end{array}$ & $\begin{array}{l}\text { Median pain score } \\
\text { higher with gel }\end{array}$ & $\begin{array}{l}10 \% \text { in the gel group } \\
\text { converted to sub-Tenon }\end{array}$ & $\begin{array}{l}P<0.000 \text { I for } \\
\text { pain }\end{array}$ \\
\hline $\begin{array}{l}\text { Soliman } \\
\text { et } \mathrm{al}^{45}\end{array}$ & 90 & $\begin{array}{l}2 \% \text { lidocaine gel } \\
0.4 \% \text { benoxinate drops }\end{array}$ & Bupivacaine $0.5 \%$ & $\begin{array}{l}\text { Lidocaine gel worse } \\
\text { at instillation, better } \\
\text { at surgery }\end{array}$ & $\begin{array}{l}\text { Conversion to sub-Tenon } \\
\text { lower for lidocaine } \\
\text { and bupivacaine }\end{array}$ & $\begin{array}{l}P<0.00 \text { I for } \\
\text { pain and for } \\
\text { patient satisfaction }\end{array}$ \\
\hline
\end{tabular}


Table 6 Comparisons between tetracaine eye drops and lidocaine gel in cataract surgery

\begin{tabular}{|c|c|c|c|c|c|c|}
\hline \multirow[t]{2}{*}{ Author } & \multirow[t]{2}{*}{$\mathbf{n}$} & \multirow[t]{2}{*}{ Tetracaine } & \multirow[t]{2}{*}{ Lidocaine } & \multirow{2}{*}{$\begin{array}{l}\text { Primary outcome } \\
\text { Study versus control }\end{array}$} & \multirow{2}{*}{$\frac{\text { Secondary outcome }}{\text { Study versus control }}$} & \multirow[t]{2}{*}{$P$ value } \\
\hline & & & & & & \\
\hline $\begin{array}{l}\text { Barequet } \\
\text { et } \mathrm{al}^{46}\end{array}$ & 25 & $0.5 \%$ drops & $2 \%$ gel & $\begin{array}{l}\text { Corneal sensitivity }(0-6) \text { : } \\
\text { Before instillation: } 5 \text { versus } 6 \\
5 \text { minutes post instillation: } 0 \text { versus } 0 \\
\text { After surgery: } 0 \text { versus } 0\end{array}$ & $\begin{array}{l}\text { Need for additional anesthetic drops: } \\
\text { Tetracaine } 31 \% \\
\text { Lidocaine } 17 \%\end{array}$ & $\begin{array}{l}P<0.0 \text { I for } \\
\text { additional drops }\end{array}$ \\
\hline $\operatorname{Harman}^{47}$ & 100 & $0.5 \%$ drops & $2 \%$ gel & Same pain reported by the two groups & Same systolic blood pressure & $P$ not significant \\
\hline $\begin{array}{l}\text { Amiel and } \\
\text { Koch }^{48}\end{array}$ & 100 & $0.5 \%$ gel & $2 \%$ gel & Same pain scores in the two groups & $\begin{array}{l}\text { I patient with lidocaine } \\
\text { required intracameral } \\
\text { anesthesia }\end{array}$ & $P$ not significant \\
\hline $\begin{array}{l}\text { Tsoumani } \\
\text { et } \mathrm{al}^{49}\end{array}$ & 51 & $0.5 \%$ drops & $2 \%$ gel & $\begin{array}{l}\text { Same pain score in the two groups: } \\
4.19 \pm 2.32 \text { versus } \\
3.88 \pm 2.72\end{array}$ & $\begin{array}{l}\text { Males and not accompanied } \\
\text { patients showed less pain }\end{array}$ & $P$ not significant \\
\hline Irle et $\mathrm{a}^{50}$ & III & $1.0 \%$ drops & $2 \%$ gel & $\begin{array}{l}\text { Pain score lower with tetracaine } \\
\text { ( } 1.77 \text { versus } 2.22 \text { ) }\end{array}$ & $\begin{array}{l}\text { "Negligible pain" } 84 \% \text { with drops, } \\
74 \% \text { with gel }\end{array}$ & $\begin{array}{l}P=0.043 \text { for } \\
\text { pain score }\end{array}$ \\
\hline $\begin{array}{l}\text { Chalam } \\
\text { et a }\left.\right|^{51}\end{array}$ & 122 & $0.5 \%$ gel & $2 \%$ gel & $\begin{array}{l}\text { Pain score lower with tetracaine: } \\
0.70 \pm 0.3 \text { I versus } I .8 \pm 0.4 \\
\text { with lidocaine }\end{array}$ & $\begin{array}{l}\text { Same patient comfort } \\
\text { Same surgeon satisfaction }\end{array}$ & $\begin{array}{l}P<0.001 \text { for } \\
\text { pain score }\end{array}$ \\
\hline
\end{tabular}

without the need to answer questions. Their advantages are their simplicity and the numeric outcome, but excessive simplicity fails to consider external influencing factors. As pointed out by Tsounami et al, ${ }^{49}$ pain sensations are greatly affected by factors that are not related to the actual amount of pain perceived during surgery. Helped by psychologists, they discovered that males complained less than females, and that the presence of accompanying persons was associated with more pain, with the differences being statistically significant. Therefore, many variables should be considered when planning or reviewing small sample studies. For this reason, it may be difficult to detect small differences in pain using a visual scale, unless a very large number of eyes are recruited.

A difference between the efficacy of the two drugs was encountered in two studies. After studying 111 patients, Irle et al found better activity for tetracaine eye drops, with a lower pain score at surgery $(1.77$ versus $2.22, P=0.043) .{ }^{50}$ Negligible pain was reported by $84 \%$ with tetracaine and by $74 \%$ with lidocaine (not statistically significant).$^{50}$ However, the tetracaine concentration used was $1.0 \%$, which is double that used by other investigators. The second study published in 2009 by Chalam et al demonstrates the superior effect of tetracaine $0.5 \%$ versus lidocaine $2 \%$ gel, ${ }^{51}$ but a gel preparation of both compounds was used. Although no comparison between tetracaine drops and tetracaine gel was published, this might suggest better efficacy of the gel formulation. The presence of benzalkonium chloride in the gel, a preservative agent that damages the corneal epithelium and improves drug penetration, is a probable explanation for the better results with tetracaine in this study.

\section{Safety}

The ocular surface may be affected by topically applied drugs. Although most of the impairment takes place following prolonged exposure, as is the case for glaucoma medications, some damage might also come from short-term exposure, like that of anesthetic agents applied before cataract surgery. To avoid damage coming from preservatives, often causing epithelial swelling with decreased visibility, ${ }^{12}$ single-use vials are preferred. Tetracaine eye drops are available as single-use vials, but the multidose gel preparation contains several nonactive chemical compounds, including benzalkonium chloride, that might affect the ocular surface. Lidocaine gel is also not available in single-use units, and the available preparations usually contain methylparaben, propylparaben, hypromellose, and sodium hydroxide and/or hydrochloric acid to adjust the $\mathrm{pH}$ to 6.0-7.0. Despite the several components, no side effects on the ocular surface have been reported that could be attributed to use of either tetracaine or lidocaine gel. On the contrary, improved wetting of the corneal surface has been reported with lidocaine gel. ${ }^{37}$ The safety of surgery as determined by complication rates also appears to be the same with either tetracaine or lidocaine. No paper has reported any difference concerning intraoperative complications, suggesting that both drugs are suitable as anesthetic agents for cataract surgery.

Topically applied tetracaine is rapidly absorbed by tissues and is rapidly degraded by tissue esterases. In contrast, topically applied lidocaine is absorbed by tissues and transferred to the liver where degradation takes place. However, systemic levels of lidocaine following topical/ intracameral administration were always found to be very 
low and no systemic activity is expected during routine cataract surgery. ${ }^{52}$

\section{Patient and surgeon perspectives}

Not surprisingly, patients were delighted by the advent of topical anesthesia for cataract surgery. Retrobulbar or peribulbar needle injection was the most feared part of the procedure, and general sedation was required more to administer the anesthesia than to perform surgery. As a consequence, sedation was discontinued soon after discontinuing the injections. The preference for topical anesthesia occurs despite the discomfort occasionally reported during surgery and in the postoperative period as compared with peribulbar injections. ${ }^{53}$

From published comparisons, we may argue that patients have no preference for tetracaine eye drops or lidocaine gel as an anesthetic agent, but a detailed study of this issue and patient perspectives is not available. Pain on instillation might be greater for tetracaine because of the lower $\mathrm{pH}$, but with a rapid onset of analgesia as a result of reduced stinging.

Surgeons need topical anesthesia for cataract surgery for two main reasons. First, because this is a high-volume activity, repeated instillations might be a problem in a busy practice, so a gel preparation of the active compound might be preferred. Second, patients are required not to react during surgery, and so far adjunctive intracameral lidocaine either routinely or occasionally both with tetracaine and with lidocaine has proven to be effective in obtaining almost the same level of analgesia as that of peribulbar injections. ${ }^{31,44,48}$

\section{Conclusion}

At the moment we can conclude that both topically applied tetracaine solution and lidocaine gel are equally effective in providing analgesia for cataract surgery. Tetracaine, usually employed at the $0.5 \%$ concentration, was found to be better only when applied at the $1.0 \%$ concentration or in the form of gel. Tetracaine has the disadvantages of more stinging at first instillation and of requiring repeated applications. However, its shorter duration of action on the corneal nerves might reduce postoperative dry sensations. Lidocaine gel has the advantages of a single application and better wetting of the cornea, and might be preferred when prolonged surgery is anticipated. However, the more prolonged duration of action on the corneal nerves might increase the dry eye sensation in the immediate postoperative period. Both drugs have a definite place in ophthalmic surgery, and at the moment the surgeon's choice between them will depend more on personal preferences than on published results.

\section{Disclosure}

Roberto Bellucci is a consultant to Bausch and Lomb. Otherwise, neither of the authors has any financial interest in this work.

\section{References}

1. Behndig A, Montan P, Stenevi U, Kugelberg M, Lundström M. One million cataract surgeries: Swedish National Cataract Register 1992-2009. J Cataract Refract Surg. 2011;37:1539-1545.

2. Arshinoff SA, Bastianelli PA. Incidence of postoperative endophthalmitis after immediate sequential bilateral cataract surgery. $J$ Cataract Refract Surg. 2011;37:2105-2114.

3. Leivo T, Sarikkola AU, Uusitalo RJ, Hellstedt T, Ess SL, Kivelä T. Simultaneous bilateral cataract surgery: economic analysis; Helsinki Simultaneous bilateral cataract surgery study report 2. J Cataract Refract Surg. 2011;37:1003-1008.

4. Fichman RA. Topical anaesthesia. In: Gills JP, Hustead RF, Sanders DR, editors. Ophthalmic Anesthesia. Thorofare, NJ: Slack Inc; 1993.

5. Bellucci R. Topical anaesthesia for small incision cataract surgery. Dev Ophthalmol. 2002;34:1-12.

6. Cyriac IC, Pineda R 2nd. Postoperative complications of periocular anesthesia. Int Ophthalmol Clin. 2000;40:85-91.

7. Nouvellon E, Cuvillon P, Ripart J, Viel EJ. Anesthesia for cataract surgery. Drugs Aging. 2010;27:21-38.

8. Patel BC, Burns TA, Crandall A, et al. A comparison of topical and retrobulbar anesthesia for cataract surgery. Ophthalmology. 1996;103: 1196-1203.

9. Bellucci R. Anesthesia for cataract surgery. Curr Opin Ophthalmol. 1999;10:36-41.

10. Bellucci R, Morselli S. Topical and intracameral anesthesia for cataract surgery. In: Kohnen T, Koch D, editors. Cataract and Refractive Surgery. Berlin, Germany: Springer; 2005.

11. Marr MG, Wood R, Senterfit L, Sigelman S. Effect of topical anesthetics on regeneration of corneal epithelium. Am J Ophthalmol. 1957;43: 606-610.

12. Sun R, Hamilton RC, Gimbel HV. Comparison of 4 topical anesthetic agents for effect and corneal toxicity in rabbits. $J$ Cataract Refract Surg. 1999;25:1232-1236.

13. Covino BG. Pharmacology of local anaesthetic agents. Br J Anaesth. 1986;58:701-716.

14. Grabow HB. Topical anesthesia for cataract surgery. Eur J Implant Refract Surg. 1993;5:20-24.

15. Kershner RM. Topical anesthesia for small incision self-sealing surgery; a prospective evaluation of the first 100 patients. $J$ Cataract Refract Surg. 1993;19:290-292.

16. Williamson $\mathrm{CH}$. Clear corneal incision with topical anesthesia. In: Gills JP, Hustead RF, Sanders DR, editors. Ophthalmic Anesthesia. Thorofare, NJ: Slack Inc; 1993.

17. Mathew MR, Webb LA, Hill R. Surgeon experience and patient comfort during clear corneal phacoemulsification under topical local anesthesia. J Cataract Refract Surg. 2002;28:1977-1981.

18. Anderson CJ. Circumferential perilimbal anesthesia. J Cataract Refract Surg. 1996;22:1009-1012.

19. Maclean H, Burton T, Murray A. Patient comfort during cataract surgery with modified topical and peribulbar anesthesia. $J$ Cataract Refract Surg. 1997;23:277-283.

20. Patel BCK, Burns TA, Crandall A, et al. A comparison of topical and retrobulbar anesthesia for cataract surgery. Ophthalmology. 1996;103: 1196-1203.

21. Patel BCK, Clinch TE, Burns TA, Shomaker ST, Jessen R, Crandall AS. Prospective evaluation of topical versus retrobulbar anesthesia: A converting surgeon's experience. J Cataract Refract Surg. 1998;24:853-860.

22. Fichman RA. Use of topical anesthesia alone in cataract surgery. J Cataract Refract Surg. 1996;22:612-614. 
23. Hoh HB, Bourne R, Baer R. Visual recovery after phacoemulsification using topical anesthesia. J Cataract Refract Surg. 1998;24: $1385-1389$.

24. Monestam E, Kuusik E, Wachtmeister L. Topical anesthesia for cataract surgery: a population-based perspective. J Cataract Refract Surg. 2001;27:445-451.

25. Irle S, Lückefahr MH, Tomalla M. Topical anesthesia as routine procedure in cataract surgery - evaluation of pain and complications in 1010 cases. Klin Monbl Augenheilkd. 2005;222:36-40. German.

26. Carino NS, Slomovic AR, Chung F, Marcovich AL. Topical tetracaine versus topical tetracaine plus intracameral lidocaine for cataract surgery. J Cataract Refract Surg. 1998;24:1602-1608.

27. Ho AL, Zakrzewski PA, Braga-Mele R. The effect of combined topicalintracameral anesthesia on neuroleptic requirements during cataract surgery. Can J Ophthalmol. 2010;45:52-57.

28. Kaluzny BJ, Kazmierczak K, Laudencka A, Eliks I, Kaluzny JJ. Oral acetaminophen (paracetamol) for additional analgesia in phacoemulsification cataract surgery performed using topical anesthesia. Randomized double-masked placebo-controlled trial. J Cataract Refract Surg. 2010;36:402-406.

29. Johnston RL, Whitefield LA, Giralt J, et al. Topical versus peribulbar anesthesia, without sedation, for clear corneal phacoemulsification. J Cataract Refract Surg. 1998;24:407-410.

30. Rüschen H, Celaschi D, Bunce C, Carr C. Randomised controlled trial of sub-Tenon's block versus topical anesthesia for cataract surgery: a comparison of patient satisfaction. Br J Ophthalmol. 2005;89:291-293.

31. Fazel MR, Forghani Z, Aghadoost D, Fakharian E. Retrobulbar versus topical anesthesia for phacoemulsification. Pak J Biol Sci. 2008;11:2314-2319.

32. Hamilton R, Claouè C. Topical anaesthesia: proxymetacaine versus amethocaine for clear corneal phacoemulsification. J Cataract Refract Surg. 1998;24:1382-1384.

33. Tan CS, Fam HB, Heng WJ, Lee HM, Saw SM, Au Eong KG. Analgesic effect of supplemental intracameral lidocaine during phacoemulsification under topical anesthesia: a randomised controlled trial. $\mathrm{Br} J$ Ophthalmol. 2011;95:837-841.

34. Behndig A, Linden C. Aqueous humor lidocaine concentrations in topical and intracameral anesthesia. J Cataract Refract Surg. 1998;24: 1598-1601.

35. Bellucci R, Morselli S, Pucci V, Zordan R, Magnolfi G. Intraocular penetration of topical lidocaine. J Cataract Refract Surg. 1999;25: 643-647.

36. Li XM, Hu L, Hu J, Wang W. Investigation of dry eye disease and analysis of the pathogenic factors in patients after cataract surgery. Cornea. 2007;26 Suppl 1:S16-S20.

37. Kalyanasundaram TS, Hasan M. Corneal-wetting property of lignocaine 2\% jelly. J Cataract Refract Surg. 2002;28:1444-1445.

38. Assia EI, Pras E, Yehezkel M, Rotenstreich Y, Jager-Roshu S. Topical anesthesia using lidocaine gel in cataract surgery. J Cataract Refract Surg. 1999;25:635-639.
39. Kwok AKH, Lai TYY, Lee VYW, Yeung Y, Chu K, Pang CCP. Effect of application duration of $2 \%$ lidocaine jelly on aqueous lidocaine concentration for topical anesthesia in cataract surgery. Graefes Arch Clin Exp Ophthalmol. 2006:244:1096-1100.

40. von Jagow B, Wirbelauer C, Häberle H, Pham DT. Early visual recovery after cataract surgery using topical and intracameral anesthesia. Klin Monbl Augenheilkd. 2007;224:585-589. German.

41. Walheeb S. Topical anesthesia in phacoemulsification. Oman $J$ Ophthalmol. 2010;3:136-139.

42. Koch PS. Efficacy of lidocaine $2 \%$ jelly as a topical agent in cataract surgery. J Cataract Refract Surg. 1999;25:632-634.

43. Bardocci A, Lofoco G, Perdicaro S, Ciucci F, Manna L. Lidocaine 2\% gel versus lidocaine $4 \%$ unpreserved drops for topical anesthesia in cataract surgery: a randomized controlled trial. Ophthalmology. 2003;110:144-149.

44. Sekundo W, Dick HB, Schmidt JC. Lidocaine-assisted xylocaine jelly anesthesia versus one quadrant sub-Tenon infiltration for self-sealing sclerocorneal incision routine phacoemulsification. Eur J Ophthalmol. 2004; 14:111-116.

45. Soliman MM, Macky TA, Samir MK. Comparative clinical trial of topical anaesthetic agents in cataract surgery: lidocaine $2 \%$ gel, bupivacaine $0.5 \%$ drops, and benoxinate $0.4 \%$ drops. J Cataract Refract Surg. 2004;30:1716-1720.

46. Barequet IS, Soriano ES, Green WR, O'Brien TP: Provision of anesthesia with single application of lidocaine $2 \%$ gel. J Cataract Refract Surg. 1999;25:626-631.

47. Harman DM. Combined sedation and topical anesthesia for cataract surgery. J Cataract Refract Surg. 2000;26:109-113.

48. Amiel H, Koch PS. Tetracaine hydrochloride $0.5 \%$ versus lidocaine $2 \%$ jelly as a topical anaesthetic agent in cataract surgery. J Cataract Refract Surg. 2007;33:98-100.

49. Tsoumani AT, Asproudis IC, Damigos D. Tetracaine $0.5 \%$ eye drops with or without lidocaine $2 \%$ gel in topical anesthesia for cataract surgery. Clin Ophthalmol. 2010;4:967-970.

50. Irle S, Lückefahr MH, Tho Seeth T. Tetracaine drops versus lidocaine gel for topical anesthesia in cataract surgery. Klin Monbl Augenheilkd. 2003;220:625-628. German.

51. Chalam KV, Murthy RK, Agarwal S, Gupta SK, Grover S. Comparative efficacy of topical tetraVisc versus lidocaine gel in cataract surgery. BMC Ophthalmol. 2009;9:7.

52. Wirbelauer C, Iven H, Bastian C, Laqua H. Systemic levels of lidocaine after intracameral injection during cataract surgery. J Cataract Refract Surg. 1999;25:648-651.

53. Nielsen PJ, Allerød CW. Evaluation of local anesthesia techniques for small incision cataract surgery. J Cataract Refract Surg. 1998;24: $1136-1144$
Open Access Surgery

\section{Publish your work in this journal}

Open Access Surgery is an international, peer-reviewed, open access journal that focuses on all aspects of surgical procedures and interventions. Patient care around the peri-operative period and patient outcomes post surgery are key topics. All grades of surgery from minor cosmetic interventions to major surgical procedures are covered. Novel techniques Submit your manuscript here: http://www.dovepress.com/open-access-surgery-journal

\section{Dovepress}

and the utilization of new instruments and materials, including implants and prostheses that optimize outcomes constitute major areas of interest. The manuscript management system is completely online and includes a very quick and fair peer-review system. Visit http://www.dovepress.com/ testimonials.php to read real quotes from published authors. 